Article

\title{
On the Process of Including Shipping in EU Emissions Trading: Multi-Level Reinforcement Revisited
}

\author{
Jørgen Wettestad * and Lars H. Gulbrandsen \\ Fridtjof Nansen Institute, Norway \\ * Corresponding author (jwettestad@fni.no)
}

Submitted: 30 August 2021 | Accepted: 26 January 2022 | Published: 17 March 2022

\begin{abstract}
As part of the EU Green Deal initiative in 2019, the EU Commission decided to develop a proposal to include emissions from shipping in the EU emissions trading system. This occurred only one year after the Commission had heralded the emissions reduction agreement negotiated in the International Maritime Organization (IMO) as a significant step forward-thereby signalling support for the IMO process. We apply a multi-level reinforcement perspective to explain this apparent policy volte-face, resulting in a Commission proposal in July 2021 which is now moving through institutions in the EU. Such a perspective notes the "friendly" competition for leadership among central actors at various levels in the EU-particularly the Commission, the European Parliament, and leading member states. We find, first, that the inclusion of shipping is in line with the broadening ambitions of the Commission since the start of the emissions trading system. Second, until 2019, the Parliament carried the regulatory torch. A turning point in the policymaking process was the inclusion of the shipping issue in Ursula von der Leyen's programme for getting accepted by the Parliament and elected as Commission leader in 2019. From then on, the Commission again took the lead. Third, despite the 2018 IMO agreement, progress there was deemed slow, which further motivated EU policymakers to act unilaterally.
\end{abstract}

\section{Keywords}

emissions trading; ETS; European Union; Green Deal; International Maritime Organization; shipping emissions

\section{Issue}

This article is part of the issue “Carbon Pricing Under Pressure: Withering Markets?" edited by Jørgen Wettestad (Fridtjof Nansen Institute) and Lars H. Gulbrandsen (Fridtjof Nansen Institute).

(C) 2022 by the author(s); licensee Cogitatio (Lisbon, Portugal). This article is licensed under a Creative Commons Attribution 4.0 International License (CC BY).

\section{Introduction}

The EU emissions trading system (ETS) initially targeted the power sector and energy-intensive industries, although with the declared ambition of covering more sectors and emissions over time. A major broadening of scope came in 2012 when EU-internal aviation was included in the ETS. Next, in 2013 the European Commission (hereafter Commission) issued a shipping strategy that took note of the regulatory progress underway within the International Maritime Organization (IMO), but also stated that more action was needed (European Commission, 2013). Negotiations within the IMO were crowned with success in April 2018, with the adoption of a strategy that included both a target of halving shipping emissions by 2050 (against a 2008 baseline) and a zero-emissions vision. Then EU Commissioner for Energy and Climate Action Miguel Arias Cañete stated: "The agreement reached today at the IMO is a significant step forward in the global efforts to tackle climate change. The shipping sector must contribute its fair share to the goals of the Paris Agreement" (Directorate-General for Climate Action, 2018).

However, no more than a year after the IMO agreement, the Commission announced a new drive to include shipping emissions in the ETS-a drive which seems to have been little affected by the Covid-19 pandemic and the related reduction in transport activities. This process 
culminated with a formal proposal to extend the EU ETS to certain shipping emissions by the Commission in July 2021, as part of the "Fit for 55" package of measures. This package is now moving through the EU institutions in a process likely to take several years to complete. How can we best understand this political process and puzzling turnaround by the Commission?

In 2007, Miranda Schreurs and Yves Tiberghien launched the concept of "multi-level reinforcement" to explain EU efforts to exert global climate leadership (Schreurs \& Tiberghien, 2007). The essence of this perspective is a competition for leadership among central actors at different levels in the EU-particularly the Commission, the European Parliament (hereafter Parliament), and leading member states in the Councilcreating a collective dynamic not achievable by one of these actors working in isolation. Here we revisit and update this perspective to shed light on the process of including shipping in the EU ETS, seen as part of a new effort to exert EU climate leadership. The shipping process reveals the increasingly important role played by the Parliament in the multi-level reinforcement dynamic, and also the importance of giving more weight to interaction with the EU-external environment in this dynamic.

\section{Analytical Framework and Method}

The essence of the multi-level reinforcement (MLR) perspective, as presented by Schreurs and Tiberghien (2007), is that EU leadership in climate change can be seen as the result of a dynamic process of multi-level competition for leadership and reinforcement among different EU political poles within a context of decentralized governance: the actions and commitments of a group of pioneering states and the leadership roles played by the Parliament and the Commission. This upward cycle of reinforcing leadership within a quasi-federal system is seen as triggered by and dependent upon strong public support and normative commitment. Schreurs and Tiberghien also acknowledge the role of interaction with the EU-external environment-however, without saying much about the dynamics.

Jordan et al. (2012) found the MLR perspective useful but refined it in several ways. Importantly, they placed it in a broader historical context, also noting periods of slow progress and no MLR dynamic functioning-as was often the case before the 2000s. Writing in the aftermath of the failure of the 2009 Copenhagen summit on climate change, and with the effects of the financial crisis putting EU climate policy under pressure, they concluded: "Consequently, one is left wondering whether 'multi-level reinforcement' is likely to persist, or was only a feature of one particularly dynamic but ultimately short-lived era of governing in the EU" (Jordan et al., 2012, p. 61). Jänicke and Quitzow (2017) have noted the relatively strong performance of the $\mathrm{EU}$ on emissions reductions, highlighting this as the outcome of mutually reinforcing dynamics at different levels of governance, explicitly linking back to Schreurs and Tiberghien.

As to the role of the central, individual MLR actors and institutions in shaping EU climate-policy leadership, recent studies have emphasized the role of the Commission in exerting various types of leadership, including a "green" response to the Covid-19 pandemic (see Dupont et al., 2020; Skjærseth, 2017). Others have highlighted the role of pioneering leader states and the dynamics in the Council (Wurzel et al., 2019). Also, the continuing "green force" role of the Parliament has been noted but with significant emphasis on internal divisions and challenges such as the influx of right-wing representatives in the 2014 election (see Burns, 2012, 2019; Buzogany \& Cetkovic, 2021; Wendler, 2019; Wettestad \& Jevnaker, 2016). In this article, we use the MLR perspective as an analytical lens to examine the political process leading up to the decision to include international shipping in the EU ETS. Our analysis sheds light on whether this perspective offers insights applicable primarily to one specific policy process at a particular time (Jordan et al., 2012) - or has wider application to the study of EU policymaking processes.

We reconstruct the shipping inclusion process by process tracing (see George \& Bennett, 2005), using data from public records, position papers, media coverage, and semi-structured interviews with central policymakers and close observers of EU policymaking (see list in our Supplementary File). Process tracing enabled us to identify chains of events, path dependencies, and critical junctures that eventually resulted in the Commission proposal to include shipping in the EU ETS.

\section{The EU Process of Including Shipping in the EU ETS: Chronological Overview}

\subsection{Designing the EU ETS, the First Revision in 2008, and Initial IMO Regulation}

The EU started to develop its EU ETS in 1998, with the Commission tabling a proposal for a Directive in 2001. The initial focus was on large emitters within the industry; the power sector was a key target group, but many energy-intensive industries were also included (Skjærseth \& Wettestad, 2008; Wettestad, 2005). The 2000 Green Paper stated that it would be logical to start with the large point-sources, followed by a gradual broadening ambition over time (European Commission, 2000, p. 10).

In mid-2008 came a first extension of the scope of the ETS: It was decided that the aviation sector was to be included in the ETS from 2012 on. The initial ambition was to include flights within as well as into and out of the EU (Anger \& Köhler, 2010). However, the main changes to ETS design for the third trading phase-to run from 2013 to 2020-were decided as part of the climate and energy package in December 2008, in order to contribute to long-term predictability for industry and all 
actors involved. Mixed experiences in the pilot phase had shown the need for significant changes. The outcome was a far more harmonized, centralized, and auctioningbased system adopted in 2008, to govern the system in the third phase. The scope was to be somewhat further broadened by including the aluminium sector (Boasson \& Wettestad, 2013; Skjærseth \& Wettestad, 2010).

As to greenhouse gas (GHG) emissions from international shipping, the UNFCCC began to address such emissions in 1995, but states could not agree on the allocation of shipping emissions to contributing states (Shi \& Gullett, 2018, p. 137). With states unable to overcome disagreement over allocation principles and proper regulation of GHG shipping emissions in the UNFCCC negotiations, the UNFCCC chose to transfer to the IMO the responsibility for addressing this issue (Shi \& Gullett, 2018, p. 137). Article 2(2) of the 1997 UNFCCC Kyoto Protocol recognizes the authority of the IMO to regulate GHG emissions from international shipping.

In the same year as the Kyoto Protocol was agreed upon, the International Convention for the Prevention of Pollution From Ships (MARPOL) conference adopted Resolution 8 on $\mathrm{CO}_{2}$ emissions from ships. That resolution requested the IMO to conduct a study on GHG emissions and to consider strategies for $\mathrm{CO}_{2}$ reduction. Eventually, in 2003, the IMO adopted a resolution on "IMO policies and practices related to the reduction of greenhouse gases from ships," urging the IMO to devise appropriate mechanisms. In the following years, the IMO continued to work on this issue. As to the status of various EU actors in the IMO, the member states are the core actors as contracting parties, with the Commission holding accredited observer status and the Parliament on the sidelines, but still communicating with the actors on the inside (Earsom \& Delreux, 2021).

\subsection{IMO Progress, EU Inclusion of Aviation in 2012, and the 2013 Maritime Strategy}

In July 2011, a milestone was reached within the IMO, when it was decided that GHG emissions from international shipping would be regulated through amendments to Annex VI of the MARPOL 73/78. These amendments introduced a mandatory Energy Efficiency Design Index (EEDI) for new ships and a Ship Energy Efficiency Management Plan (SEEMP) for all ships. The IMO also discussed various possibilities for introducing market-based mechanisms, including a global ETS (proposed by France, Germany, Norway, and the UK), a GHG fund, a port-state levy, and a ship efficiency and credit trading scheme (Shi \& Gullett, 2018). However, the parties were unable to agree on how to proceed regarding market-based mechanisms. Instead, they agreed to work on a US proposal to improve the energy efficiency of ships through technical and operational measures (Shi \& Gullett, 2018).

In 2012, the scope of the ETS was extended to airlines. Airlines were given a majority of allowances for free $(82 \%)$ and could not sell allowances into the system.
However, due to considerable opposition from the USA and other actors, only intra-EU flights were included (Vihma \& van Asselt, 2014).

In 2013 the Commission published a communication on integrating maritime transport emissions in the EU's GHG reduction policies (European Commission, 2013). This communication recognized that international maritime transport emissions remained the sole transport mode not included in the EU's GHG commitment, even though these emissions were expected to increase significantly (European Commission, 2013, p. 2). It was also noted that the shipping sector was a key sector for the EU economy. Concerning GHG regulatory action, the communication mentioned the work of the IMO, dating back to 1997, MARPOL, and other conventions. It also described work on efficiency measures, market-based measures, and developing systems for monitoring, reporting, and verification (MRV) being conducted by the EU in collaboration with Australia, Japan, the USA, and other states.

As to the EU's general vision on international cooperation in this issue-area at this time, the communication noted: "The EU has a strong preference for a global approach led by the IMO as the most appropriate forum to regulate emissions from shipping" (European Commission, 2013, p. 4, our italics). But the next sentence noted the "slow pace of the IMO discussions," indicating a certain degree of impatience. Furthermore, the gradual inclusion of maritime GHG emissions in the EU's reduction commitment was indicated, with an approach "to be considered" that would consist of three key elements: (a) implementing a system for MRV of emissions; (b) defining reduction targets for the maritime transport sector; and (c) applying a market-based mechanism (European Commission, 2013, p. 5). Again, however, reference to the IMO link was repeated: “The EU's approach is designed to actively contribute to an agreement on global measures to reduce GHG emissions from ships in the IMO" (European Commission, 2013, p. 5; see also p. 9).

The MRV part was then followed up by the adoption of such an EU system in 2015 (Regulation 2015/757 of the European Parliament and of the Council of 29 April $2015,2015)$. Here, the EU required ships of above 5,000 gross tonnage to monitor and report their carbon emissions, fuel consumption, and transport work on all voyages to, from, and between EU ports. The first monitoring period was to be from January to December 2018.

The general ETS agenda at this point was dominated by discussions on how to respond to the low carbon price resulting from the surplus of allowances, caused largely by the financial crisis post-2008. The Parliament played a fairly ambiguous role: After initially voting down ETS reform in the spring of 2013, the dynamics changed and 2015 saw the adoption of a market stability reserve (MSR), to start functioning from 2019. Paving the way for the 2015 decision, key ETS reform sceptics left the EU Parliament after the 2014 elections (Wettestad \& Jevnaker, 2016). 


\subsection{EU ETS and Maritime Politics Leading Up to the Green Deal}

The MSR had been adopted through a separate decision. The decision-making focus now shifted to the revision of the ETS Directive itself, preparing the ETS for the fourth trading period (2021-2030). Following specific instructions from the October 2014 European Council meeting, which included an overall $40 \% 2030$ emissions reduction target, the Commission tabled a proposal in July 2015. This involved an updated 2030 cap, prolonged provisions for solidarity to low-income member states, the continuation of carbon leakage arrangements (with some revisions), and two new funds: (a) an innovation fund to support industry decarbonisation and (b) a modernisation fund to assist the energy transition and move away from coal, especially in Eastern Europe.

On the global climate politics scene, the Paris Agreement was adopted in December 2015, establishing a fundamentally decentralized policy architecture for the years ahead. The Kyoto Protocol's binding targets for countries and regions were replaced by the overall temperature-focused target of limiting global warming to well below $2^{\circ} \mathrm{C}$, while pursuing efforts to limit it to $1.5^{\circ} \mathrm{C}$, accompanied by regular reviews and ratcheting up (Dimitrov, 2016). In 2016, Donald Trump was elected US President; in 2017, he declared that the USA would withdraw from the Paris Agreement, which angered politicians in the EU bodies and most member states (see "EU mulls economic measures," 2017).

In October 2016, IMO member states agreed on a roadmap for adopting a GHG emissions reductions strategy within two years. In the ensuing negotiations, a dynamic developed whereby a majority of EU member states (including Belgium, France, Germany, and the Netherlands) and the EU Presidency played important roles, in collaboration with entrepreneurial states in the IMO, the Marshall Islands in particular. This took place in the Shipping High Ambition Coalition (SHAC) as described by Earsom and Delreux (2021). But other EU member states, among them Cyprus, Greece, and Malta, were footdraggers. Moreover, EU Parliamentarians allegedly acted more as "bad cops," threatening unilateral EU action on this issue (Earsom \& Delreux, 2021, p. 407).

With the carbon price remaining stubbornly low, the question of further reducing the accumulated allowance surplus came to dominate the EU ETS reform negotiations (Wettestad \& Jevnaker, 2019). However, also the issue of broadening the coverage as to sectors and activities was part of this discussion (as per our interviews from 2018). The inclusion of shipping in the ETS was particularly pushed by the Parliament. For instance, in the Environment Committee's (ENVI) first ETS reform hearing in February 2016, several members called for extending the ETS scope to more sectors such as shipping ("Five things we learned," 2016).

ENVI then adopted its position in December 2016. It was decided that shipping was to be included in the ETS from January 2023 unless a comparable system was introduced by the IMO. One-fifth of the auctioning revenues from the maritime sector should go to a new maritime climate fund that would finance energy efficiency and emissions reductions in the maritime sector ("EU Parliament's ENVI votes," 2016).

A major reform event in 2017 was the plenary session in the Parliament in mid-February. Prior to the meeting, cargo companies had supported the inclusion of shipping in the ETS, stating that "shipping remains the only sector not contributing to economy-wide decarbonisation to meet the EU's 2030 Paris target" (Crisp, 2017). The plenary position was adopted by a comfortable majority (379 in favour, 263 against, 57 abstentions), and generally supported the ENVI position, including on shipping (European Parliament, 2017).

This was followed later in February by the Council agreeing on a common ETS reform position, one which proved generally more ambitious than that of the Parliament. However, among the many issues on the agenda, there was no mention of shipping. That explains why the shipping issue was not among the key issues that came to dominate the subsequent trilogue meetings in 2017: strengthening the ETS and increasing the MSR intake; carbon leakage protection; and low-carbon financing and support mechanisms. Still, according to shipping sources, the shipping issue had proven "contentious throughout the entire negotiation process" (Offshore Energy, 2017).

Although the shipping issue did not dominate the headlines, it was included in the final reform outcome of November 2017. This outcome adopted a framework for the 2021-2030 phase which included both a tightening of the MSR in the period leading up to 2023 and a surplus cancellation mechanism from that point (Wettestad \& Jevnaker, 2019). As to sectoral broadening, the 2018 Directive noted that efforts to limit international maritime emissions through IMO were underway "and should be encouraged": This had become "a matter of urgency." The Commission was to keep this under regular review and report at least once a year to the Parliament and the Council on the progress achieved in the IMO towards an ambitious emissions reduction objective, and on accompanying measures to ensure that the sector contributed duly to the efforts needed to achieve the objectives agreed under the Paris Agreement (Directive 2018/410 of the European Parliament and of the Council of 14 March 2018, 2018). Central stakeholders interpreted this as a victory for the Parliament (as per our interviews from 2018).

The IMO adopted its own MRV system in 2016. Negotiations on a new emissions reductions strategy within the IMO were crowned with success in April 2018, with the adoption of a strategy that included the target of halving shipping emissions by 2050 , compared to 2008 , and a zero-emissions vision. These objectives were to be achieved by improving the energy efficiency of all ships, gradually decreasing the carbon intensity of 
new ships, and strengthening their energy performance. The choice of 2008 as the baseline for emissions was deliberate, as that was just before the financial crisis and emission peaked. The adoption of the 2018 IMO GHG reduction strategy was hailed as a major breakthrough in the efforts to regulate GHG emissions from international shipping. As noted, then EU Commissioner for Energy and Climate Action Miguel Arias Cañete described the IMO agreement as a "significant step forward." However, analysts point out that the outcome was not in line with EU preferences, for instance seeking a $70 \%$ emissions cut by 2050 (Earsom \& Delreux, 2021, p. 407). Moreover, many EU Parliamentarians still felt that IMO progress was much too slow (as per our interviews from 2021).

In the ensuing months of 2018, an important development was the gradual increase in the carbon price, with prices slightly above EUR 25 in September. However, the rest of that year saw little activity as to the sectoral extension issue, with actors in the EU institutions and the member states paying more attention to the question of a 2050 neutrality target for the EU.

\subsection{The Green Deal and the New Shipping Drive}

The first key development in 2019 was the election of a new European Parliament in May. This resulted in an increased number of seats for groupings favourable to higher climate ambitions, such as the liberals (ALDE) and the Greens (the latter up to 70 seats from the previous 51; see "EU Parliament's fragmented election," 2019; Henley, 2019).

Parliamentary elections were accompanied by the process of getting a new Commission and Commission President approved. In the July Parliamentary hearings, German presidential candidate Ursula von der Leyen promised to introduce a climate law to raise the 2030 target from $40 \%$ to $50 \%$ and achieve climate neutrality by 2050. In addition, she declared the need to broaden the ETS scope with maritime and more aviation ("Nominated Brussels chief," 2019; von der Leyen, 2019).

In a letter to the Socialists \& Democrats and the Liberal Renew Europe group in the Parliament, von der Leyen elaborated a green "comprehensive plan" for Europe (now touted as a Green Deal), with a target of at least $55 \%$, the establishment of a "just transition fund," a Sustainable Europe Investment Plan, and "the extension of the emissions trading system." In the end, von der Leyen's candidacy was approved by a moderate majority in the Parliament (383 to 327). Analysts held that her ETS plans were both "mega-bullish" but also vague, "used as a bargaining tool to get into office" ("Mega-bullish or long-shot," 2019).

In the winter of 2020, the Covid-19 crisis struck, also affecting the activities covered by the EU ETS-for example, Italy announced plans for closing all factories. Electricity use plummeted, as many commercial units were closed and the public was in lockdown. It was expected that aviation and transport generally would be hard hit.

The Green Parliamentarian Jutta Paulus was now leader and rapporteur for the shipping issue in ENVI. In late May 2020, she was reported as pushing hard for fast-track inclusion of shipping in the ETS. Germany was in favour of the measure, along with France, Ireland, Lithuania, Portugal, and Spain, while Greece, Latvia, Poland, and Romania opposed tackling maritimesector emissions outside the IMO framework. However, the initiative encountered a setback when the influential Transport Committee (TRAN) in the Parliament supported the report of TRAN Rapporteur Adamowicz, which made no mention of the ETS and supported continued alignment with IMO processes ("Lawmaker snub," 2020).

In May 2020, the Commission presented its EUR 1.85 trillion European recovery plan, including a EUR 750 billion “Next Generation EU Recovery Instrument." To repay the loan part of this package, the Commission hoped to include more of the ETS revenues raised thus far and controlled by the member states, and also add revenues from including shipping in the ETS (Roberts, 2020).

When the Parliament resumed session in September 2020 , it also debated the inclusion of shipping-which could increase the size of the ETS by almost $10 \%$. Due to the Covid pandemic, the Marine Environment Protection Committee of the IMO had indefinitely postponed a meeting to discuss the organisation's 2050 GHG emissions reduction of a minimum of $50 \%$, so the $\mathrm{EU}$ Parliament adopted an amendment to fast-track the inclusion of shipping through an amendment to the EU'S MRV regulation for maritime emissions. This would start from January 2022 and apply to emissions from ships using EU ports. Further, ship operators were to reduce their emissions by at least $40 \%$ by 2030 , compared to 2018-2019 levels. The Parliament also called for the creation of an Ocean fund based on half of the auctioning revenues raised by the inclusion of shipping ("EU Parliament supports expanding ETS," 2020; European Parliament, 2020).

In November 2020, EU negotiators finally reached an agreement on the EUR 1.074 trillion seven-year budget, at least $30 \%$ of which was to be spent on climate measures. The carbon price then shot above EUR 27. Korea and Japan expressed concern about the possible inclusion of shipping in the ETS: Given the international nature of shipping, they argued, the issue should be tackled on the global, not regional, level ("Japan, South Korea oppose move," 2020).

In December 2020, EU heads of states adopted an upgraded 2030 target of "at least 55\% emissions reductions" ("EU leaders," 2020). The spring of 2021 was dominated by final preparations on a "super package" for implementing the new 55\% target, referred to as the "Fit for 55" package. This included a shipping inclusion proposal as part of the ETS reform part of the package. In March, the Commission published consultation 
responses from a range of shipping actors and nationstates. The negative consequences of including shipping in the ETS-like carbon leakage and increased emissions due to change to land transport-were highlighted by actors such as the International Chamber of Shipping, European Community Shipowners Association, national shipowner associations, and countries that included Estonia, Japan, Malta, and the UK (European Commission, 2021a). The formal proposal, presented on 14 July 2021, had the following main elements:

- The initial coverage concerns intra-EU voyages, half of the emissions from extra-EU voyages, and emissions at berth in an EU port.

- The focus is on large ships, above 5000 gross tonnage.

- A gradual inclusion is envisaged. Shipowners will be required to be in full compliance with emissions caps only as of 2026, with a phase-in period from 2023 to 2025 . It is the responsibility of shipowners to buy and surrender units for $20 \%$ of verified emissions reported for $2023,45 \%$ of emissions for $2024,70 \%$ for 2025 , and $100 \%$ by 2026 . Over those years, the amount of allowances not surrendered will be cancelled.

- There is openness to considering amendments to the EU shipping policy in the future if the UN's IMO should introduce its own market-based measures (European Commission, 2021b).

This new "shipping drive" also included the Fuel EU Maritime Initiative, which is meant to stimulate the uptake of sustainable fuels and zero-emission technologies by setting a maximum limit on the GHG content of energy used by ships calling at European ports (European Commission, 2021c). Committees in the Parliament and member states in the Council had initial discussions of the proposal during autumn 2021, confirming overall support to the inclusion of shipping, with key Parliamentarians even seeking a quicker inclusion of shipping than that proposed by the Commission ("EU lawmakers eye quicker entry," 2021). Completing the decision-making process may take two years or even more. The previous comprehensive ETS reform process took over two years: July 2015 to November 2017 (Wettestad \& Jevnaker, 2019).

\section{Analysis: Revisiting Multi-Level Reinforcement}

The essence of the Multi-Level Reinforcement perspective is that the EU's leadership in climate change can be seen as the result of a dynamic process of competitive multi-level reinforcement among various EU political poles within a context of decentralized governance: the actions and commitments of a group of pioneering states; and the leadership roles played by the Parliament and the Commission. This upward cycle of reinforcing leadership within a quasi-federal system is triggered by and dependent upon strong public support and normative commitment (Schreurs \& Tiberghien, 2007).

Using these lenses, how can we interpret the shipping inclusion process in the EU ETS? A first thing to note from the chronological overview (Section 3 above) is that the rationale of gradually broadening EU emissions trading to more sectors than the initially targeted power industry and energy-intensive industries has been present ever since the early days of designing the initial system. Further, the initiative to include aviation in 2008 (implemented from 2012 on) must be seen in connection with the Commission seeking to exert EU leadership in a climate policy sub-issue area that had been moving too slowly at the global level.

As to shipping, the 2013 communication showed some impatience with progress at the global level, but retained its prime commitment to working within the IMO in order to make further progress. The ETS agenda in the Parliament and the member states was at this point dominated by efforts to deal with the accumulating surplus of allowances and the related depressed carbon price, due not least to the finance crisis which had hit the EU from 2009 on. The Parliament played a more ambiguous role at this stage-for instance, initially voting down ETS reform in the spring of 2013.

The role of the Parliament shifted from 2016 on, with the inclusion of shipping as one of a select few targeted ETS reform issues. What had happened? First, the 2014 elections to the Parliament had altered the internal dynamics, with key ETS reform "blockers" leaving. Second, the Paris Agreement had established new and ambitious temperature targets for the EU and the world in terms of emissions reductions. Third, the election of Trump and US disengagement with global climate politics spurred various EU actors and institutions, including the Parliament, to display strengthened EU leadership in climate policy issues. Fourth, the Parliament was growing increasingly impatient with IMO progress.

As documented in Section 3, the Parliament carried the regulatory torch up until 2019. A crucial development in the spring and summer of that year was the inclusion of the shipping issue in Ursula von der Leyen's programme to get elected as Commission leader. Various types of evidence, including interviews with central current and former EU policy-makers with differing institutional affiliations, indicate that this development can mainly be traced back to the Parliament "shipping campaign" in the preceding years, as she was fighting to get accepted by the Parliament (as per our interviews from 2021). According to one key informant, von der Leyen had to offer the Parliament something in return for their approval. The Green Deal became part of her election campaign and a key means of securing support from Parliament. When von der Leyen was elected, the shipping issue was included in the Green Deal programme. This can be seen as a critical juncture in the EU policymaking process, which changed the EU's strategy to address emissions from shipping. 
Since then, the regulatory torch has been largely taken over again by the Commission. For instance, in November 2021 EU climate commissioner Frans Timmermans explicitly blamed lacklustre IMO action for the need for a unilateral extension of the EU ETS to shipping (Ernhede, 2021). However, it should also be recalled that such inclusion was clearly in accordance with a much longer line in the Commission which favoured a gradual broadening of the scope of the ETS. This shows the value of a historical, longitudinal perspective in studying the EU ETS.

But what about the member states in the reinforcement dynamics? As documented in Section 3, in the post-2015 years a majority of the member states emphasized the need to make progress within the IMO, with the 2018 strategy as a partial success for EU positions. However, we have found no evidence of a strong member-state initiative at this stage to include shipping in the EU ETS-but most member states were not opposed to including shipping in the ETS either. The eastern EU member states are land-locked or do not have a shipping industry, and member states with a significant shipping industry (such as Denmark and the Netherlands) hold progressive attitudes to climate issues. The EU shipping states Cyprus, Greece, and Malta were opposed to strong IMO climate action that could hit them hard, but they do not seem to have campaigned hard against the proposal to include shipping in the EU ETS. A central explanation is that they realized early that fighting the proposal would be an uphill battle and they could not form a blocking minority coalition. Therefore, they decided instead to get the most out of what would be proposed by the Commission in the "Fit for 55" package (according to our interviews from 2021).

In spring 2021, EU leaders added a new dimension by declaring that the revenues from an expanded EU ETS to the maritime sector (and, over time, other transport and buildings) would contribute to funding the EU's Next Generation pandemic recovery fund. This declaration may, according to some of our informants, have increased support for including shipping in the ETS among the member states, but we lack conclusive evidence.

\section{Conclusion}

An MLR perspective can help in explaining the drive to include shipping in the ETS. This drive cannot be understood by focusing on the central EU institution and actors separately: It is their interaction and "passing of the regulatory torch" that provides the key. The election of von der Leyen as Commission President in 2019 marked a critical juncture in the policymaking process. This event eventually resulted in the Commission's proposal to include certain emissions from shipping in the EU ETS, but the push from the Parliament to secure this move proved vital for this outcome. Commission President von der Leyen's Green Deal initiative was part of her election campaign and was important for securing support from the Parliament. Therefore, the MLR perspective was not merely a feature of one short-lived era of governing in the EU (Jordan et al., 2012); we maintain that this perspective has wider application in the study of EU policymaking processes. However, this perspective seems to have explanatory power only under certain conditions and historical circumstances that open a window of opportunity for multi-level competition among central actors at several levels in the EU. Future research should examine the scope conditions and applicability of this perspective across cases in the study of EU policymaking processes. As to the process of including shipping in the ETS, negative experience with the effort to include EU-external aviation under the ETS for some years probably discouraged EU actors from doing likewise with shipping, a far more complex issue than aviation. In addition, there was uncertainty as to the outcome of the negotiations starting in the IMO from 2016 on. This indicates that the interaction with the EU-external environment is one important conditional factor for the unfolding of the MLR dynamic.

How can the ETS shipping-inclusion case contribute to updating and further refining the MLR perspective? In view of the significant EU-internal push and EU-external pull, it makes sense to distinguish explicitly between a "vertical" and "horizontal" dimension to the MLR dynamic. The vertical dimension includes interaction with the EU-external environment and sub-national dynamics. In the case of shipping, it is essential to consider developments within the IMO and the perceived slow progress there. Hence, this case seems to fit the international entrepreneurship mechanism proposed by Boasson and Wettestad (2013). This mechanism highlights how EU actors may make strategic use of developments within international regimes and organisations to shape the EU agenda-setting. In particular, actors in the Parliament cited the slow progress within the IMO to bolster the idea of including shipping in the ETS.

The horizontal dimension mainly concerns the interaction and dynamics between the "Brussels institutions" - the Commission, Parliament, and Council. A first observation here is the lack of member-state entrepreneurship in the shipping inclusion case. A likely explanation is, first, that member states were formally acknowledged actors in the IMO and felt more loyalty to that institution than did the Parliament, which was not a formally acknowledged actor in the IMO negotiations. Second, the ETS reform agenda of most member states in the period since 2015 was very much dominated by the persistent low carbon price and ways to address the issue of reducing the surplus of allowances and strengthening the carbon price. In this picture, the shipping issue (handled also by the IMO) was not a top priority among the member states. Furthermore, this case has shown the important role played by the Parliament, which should be accorded a more prominent position in an updated MLR perspective, balancing the attention given 
to the Commission in understanding EU climate leadership in recent years. A general background factor here is likely the gradual "greening" of the composition of the Parliament-not least in the 2019 elections.

\section{Acknowledgments}

The authors are grateful to the reviewers for their helpful comments and to Susan Høivik for language editing. The study was conducted as part of the Platon project (Platform for Open and Nationally Accessible Climate Policy Knowledge), funded by the Research Council of Norway (grant number 295789).

\section{Conflict of Interests}

The authors declare no conflict of interests.

\section{Supplementary Material}

Supplementary material for this article is available online in the format provided by the author (unedited).

\section{References}

Anger, A., \& Köhler, J. (2010). Including aviation emissions in the EU ETS: Much ado about nothing? A review. Transport Policy, 17(1), 38-46. https://doi. org/10.1016/j.tranpol.2009.10.010

Boasson, E. L., \& Wettestad, J. (2013). EU climate policy: Industry, policy interaction and external environment. Ashgate.

Burns, C. (2012). The European Parliament: Still the EU's environmental champion? In A. Jordan \& C. Adelse (Eds.), Environmental policy in the European Union (pp. 132-152). Routledge.

Burns, C. (2019). In the eye of the storm? The European Parliament, the environment and the EU's crises. Journal of European Integration, 41(3), 311-327.

Buzogany, A., \& Cetkovic, S. (2021). Fractionalized but ambitious? Voting on energy and climate policy in the European Parliament. Journal of European Public Policy, 28(7), 1038-1056.

Crisp, J. (2017, February 14). Cargo companies call for shipping to be regulated by EU's emissions trading market. Euractiv. https://www.euractiv.com/ section/climate-environment/news/cargocompanies-call-for-shipping-to-be-regulated-byeus-emissions-trading-market

Dimitrov, R. S. (2016). The Paris agreement on climate change: Behind closed doors. Global Environmental Politics, 16(3), 1-11.

Directive (EU) 2018/410 of the European Parliament and of the Council of 14 March 2018 amending Directive 2003/87/EC to enhance cost-effective emission reductions and low-carbon investments, and Decision (EU) 2015/1814. (2018). Official Journal of the European Union, L 76/3.
Directorate-General for Climate Action. (2018). Maritime Commissioners Bulc and Arias Cañete welcome the IMO agreement on $\mathrm{CO} 2$ reductions in the maritime sector. EC Europa. https://ec.europa.eu/clima/newsyour-voice/news/commissioners-bulc-and-ariascanete-welcome-imo-agreement-co2-reductionsmaritime-sector-2018-04-13_en

Dupont, C., Oberthür, S., \& von Homeyer, I. (2020). The Covid-19 crisis: A critical juncture for EU climate policy development? Journal of European Integration, 42(8), 1095-1110.

Earsom, J., \& Delreux, T. (2021). A nice tailwind: The EU's goal achievement at the IMO initial strategy. Politics and Governance, 9(3), 401-411.

Ernhede, C. (2021, November 10). COP26: Global transport sectors must "change their attitude," Timmerman says. Ends Europe. https://www.endseurope. com/article/1732851/cop26-global-transportsectors-change-attitude-timmermans-says

EU lawmakers eye quicker entry of shipping into ETS as clean-up costs mount. (2021, December 8). Carbon Pulse. https://carbon-pulse.com/146180

EU leaders adopt upgraded 2030 climate target of at least 55\%. (2020, December 11). Carbon Pulse. https://carbon-pulse.com/117127

EU mulls economic measures for US after Trump's withdrawal from Paris agreement. (2017, June 2). RT. https://www.rt.com/news/390657-eu-mullseconomic-measures-for-us

EU Parliament supports expanding ETS to international shipping from 2022. (2020, September 15). Carbon Pulse. https://carbon-pulse.com/109070

EU Parliament's ENVI votes for more ambitious ETS reform package. (2016, December 15). Carbon Pulse. https://carbon-pulse.com/28148

EU Parliament's fragmented election points to coalition building on climate. (2019, May 27). Carbon Pulse. https://carbon-pulse.com/75553

European Commission. (2000). Green Paper on greenhouse gas emissions trading in the European Union. https://op.europa.eu/en/publication-detail/-/ publication/41ab9f93-b438-41a6-b330bb0491f6f2fd

European Commission. (2013). Integrating maritime transport emissions in the EU's greenhouse gas reduction policies. http://shorturl.at/dltyX

European Commission. (2021a). Climate changeUpdating the EU emissions trading system (ETS). EC Europa. https://ec.europa.eu/info/law/betterregulation/have-your-say/initiatives/12660-Climatechange-updating-the-EU-emissions-trading-systemETS-_en

European Commission. (2021b). Proposal for a Directive of the European Parliament and of the Council amending Directive 2003/87/EC establishing a system for greenhouse gas emission allowance trading within the Union, Decision (EU) 2015/1814 concerning the establishment and operation of $a$ 
market stability reserve for the Union greenhouse gas emission trading scheme and Regulation (EU) 2015/757. https://eur-lex.europa.eu/legal-content/ EN/TXT/?uri=CELEX\%3A52021PC0551

European Commission. (2021c). Proposal for a Regulation of the European Parliament and the Council on the use of renewable and low-carbon fuels in maritime transport and amending Directive 2009/16/EC. https://eur-lex.europa.eu/legal-content/EN/TXT/ ?uri=CELEX\%3A52021PC0562

European Parliament. (2017, February 15). MEPs back plans to cut carbon emission allowances and fund low-carbon innovation [Press Release]. https://www. europarl.europa.eu/news/pt/press-room/20170210 IPR61806/meps-back-plans-to-cut-carbon-emissionallowances-and-fund-low-carbon-innovation

European Parliament. (2020, September 16). Parliament says shipping industry must contribute to climate neutrality [Press Release]. https://www.europarl. europa.eu/news/lv/press-room/20200910IPR86825/ parliament-says-shipping-industry-must-contributeto-climate-neutrality

Five things we learned from MEPs' first look at EU ETS reform plans. (2016, February 18). Carbon Pulse. https://carbon-pulse.com/15837

George, A. L., \& Bennett, A. (2005). Case studies and theory development in the social sciences. MIT Press.

Henley, J. (2019, May 28). European elections: Triumphant Greens demand more radical climate action. The Guardian. https://www.theguardian. com/environment/2019/may/28/greens-euelection-mandate-leverage-climate-policy

Jänicke, M., \& Quitzow, R. (2017). Multi-level reinforcement in European climate and energy governance: Mobilizing economic interests at the sub-national levels. Environmental Policy and Governance, 27, 122-136.

Japan, South Korea oppose move to bring global shipping into EU carbon market. (2020, November 26). Carbon Pulse. https://carbon-pulse.com/115817

Jordan, A., van Asselt, H., Berkhout, F., Huitema, D., \& Rayner, T. (2012). Understanding the paradoxes of multilevel governing: Climate change policy in the European Union. Global Environmental Politics, 12(2), 43-66.

Lawmaker snub could mean bid to add shipping to EU ETS drifts into doldrums. (2020, May 29). Carbon Pulse. https://carbon-pulse.com/100342

Mega-bullish or long-shot: Experts mixed over EU ETS impact of von der Leyen pledges. (2019, July 18). Carbon Pulse. https://carbon-pulse.com/78918

Nominated Brussels chief promises bill for deeper 2030 GHG cut goal. (2019, July 10). Carbon Pulse. https:// carbon-pulse.com/78367

Offshore Energy. (2017). Shipping should not be included in EU emissions trading system? https://www. offshore-energy.biz/shipping-should-not-be- included-in-eu-emissions-trading-system

Regulation (EU) 2015/757 of the European Parliament and of the Council of 29 April 2015 on the monitoring, reporting and verification of carbon dioxide emissions from maritime transport, and amending Directive 2009/16/EC. (2015). Official Journal of the European Union, L 123/55.

Roberts, N. (2020, May 28). 9 things you need to know about the EU recovery plan. Ends Europe. https:// www.endseurope.com/article/1684583/9-thingsneed-know-eu-recovery-plan

Schreurs, M. A., \& Tiberghien, Y. (2007). Multi-level reinforcement: Explaining European Union leadership in climate change mitigation. Global Environmental Politics, 7(4), 19-46.

Shi, Y., \& Gullett, W. (2018). International regulation on low-carbon shipping for climate change mitigation: Development, challenges, and prospects. Ocean Development \& International Law, 49(2), 134-156.

Skjærseth, J. B. (2017). The European Commission's shifting climate leadership. Global Environmental Politics, 17(2), 84-104.

Skjærseth, J. B., \& Wettestad, J. (2008). EU emissions trading: Initiation, decision-making and implementation. Ashgate.

Skjærseth, J. B., \& Wettestad, J. (2010). Fixing the EU emissions trading system? Understanding the post2012 changes. Global Environmental Politics, 10(4), 101-123.

Vihma, A., \& van Asselt, H. (2014). The conflict over aviation emissions: A case of retreating EU leadership? (Briefing Paper 150). Finnish Institute of International Affairs.

von der Leyen, U. (2019). A Union that strives for more: My agenda for Europe. Publications Office of the European Union. https://op.europa.eu/en/ publication-detail/-/publication/43a17056-ebf111e9-9c4e-01aa75ed71a1

Wendler, F. (2019). The European Parliament as an arena and agent in the politics of climate change: Comparing the external and internal dimension. Politics and Governance, 7(3), 327-338.

Wettestad, J. (2005). The making of the 2003 EU emissions trading directive: Ultra-quick process due to entrepreneurial proficiency? Global Environmental Politics, 5(2), 1-24.

Wettestad, J., \& Jevnaker, T. (2016). Rescuing EU emissions trading: The climate policy flagship. Palgrave.

Wettestad, J., \& Jevnaker, T. (2019). Smokescreen politics? Ratcheting up EU emissions trading in 2017. Review of Policy Research, 36(5), 635-659.

Wurzel, R. K., Lifferink, D., \& Di Lullo, M. (2019). The European Council, the Council and the member states: Changing environmental leadership dynamics in the European Union. Environmental Politics, 28(2), 248-270. 


\section{About the Authors}

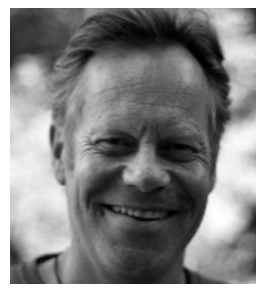

Jørgen Wettestad is a research professor at the Fridtjof Nansen Institute in Oslo, Norway. He has published several books and numerous articles on international, EU, and national environmental policy, with much attention to EU climate and energy policy. His most recent books are Comparative Renewables Policy: Political, Organizational and European Fields (edited together with Elin Lerum Boasson and Merethe Dotterud Leiren; Routledge 2021) and The Evolution of Carbon Markets: Design and Diffusion (edited with Lars H. Gulbrandsen; Routledge 2018). Wettestad is editorial board member of Politics and Governance and participates as lead author in WG III in IPCC's Sixth Assessment Report.

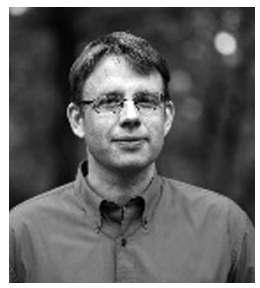

Lars H. Gulbrandsen is a research professor and research director at the Fridtjof Nansen Institute in Oslo, Norway. His main research interests are within the fields of climate and energy policy, global environmental governance, and international political economy. Much of his work has examined the emergence, evolution, and effects of sustainability certification and eco-labelling within and across sectors. He has also published widely on different aspects of climate and energy policy, environmental policy, and low carbon-transitions, including EU climate policy, emissions trading, windpower regulation and licensing, protected areas management, and forest policy. His most recent book is The Evolution of Carbon Markets: Design and Diffusion (co-edited with Jørgen Wettestad; Routledge, 2018). 